\title{
Araucaria angustifolia Budding Techniques in Indoor and Outdoor Stablished Rootstocks
}

\author{
Helena Cristina Rickli-Horst ${ }^{1}$ (D), Ivar Wendling ${ }^{2}$ (D), \\ Henrique Soares Koehler ${ }^{1}$ (D), Katia Christina Zuffellato-Ribas ${ }^{1}$ \\ ${ }^{1}$ Universidade Federal do Paraná - UFPR, Curitiba/PR, Brasil \\ ${ }^{2}$ Empresa Brasileira de Pesquisa Agropecuária - Embrapa Florestas, Colombo/PR, Brasil
}

\begin{abstract}
The objective of this work was to evaluate the technical feasibility of budding in A. angustifolia in two rootstocks establishment, performed in two seasons of the year. In October and April, patch and flute budding techniques were carried on rootstocks kept indoor (greenhouse) and established outdoor (field), with grafts of adult female plants. The percentage of survival, percentage of shoots and number of shoots up to 300 days after budding (DAB) were evaluated. The patch budding performed in October showed the greatest grafts survival rates (82\%) and percentage of shoots in the grafts $(64 \%)$ at $180 \mathrm{DAB}$. The flute budding showed highest number of shoots (2.7 at $120 \mathrm{DAB}$ and 3.5 at $180 \mathrm{DAB}$ ) when compared to patch budding. The use of the patch budding is recommended in spring, not requiring a controlled environment for the rootstocks. After 180 DAB there were no losses of grafted plants.
\end{abstract}

Keywords: brazilian-pine, grafting, greenhouse, field orchard. 


\section{INTRODUCTION}

Araucaria angustifolia (Bertol.) Kuntze (Araucariaceae), popularly known as araucaria, Brazilian pine or Paraná pine, is the main arboreal component of the Mixed Ombrophilous Forest, as well as in areas of ecological tension between the Semi-deciduous Seasonal Forest and the Dense Ombrophilous Forest (Carvalho, 2003). At the present, it is concentrated in reduced areas. With less than $5 \%$ of the original area of the Ombrophilous Mixed Forest still remaining, and due to the large logging and agricultural expansion, the species is included in the list of threatened species (IUCN, 2013).

Araucaria presents excellent wood quality, with good physical and mechanical characteristics (Carvalho, 2003). In addition, its edible seed, named as araucaria nut, is rich in carbohydrates, starch, proteins, fibers, calcium, phosphorus, iron and vitamins (Franco, 2008), with high potential for use in food technology (Stahl et al., 2007). The commercial exploitation of araucaria nuts is a viable and advantageous alternative, mainly with the aggregation of value on the product. Hence, it is a form of conservation of the species in a profitable and competitive way by reducing the illegal exploitation of remaining areas (Silveira et al., 2011; Zanette et al., 2011; Danner et al., 2012).

Proactive actions are necessary for the conservation of the species, such as incentives to producers and the formation of germplasm banks, with identification, selection and cloning of trees with high production of nuts or wood (Anselmini \& Zanette, 2012).

It is important to note the delay in the production of $A$. angustifolia nuts, which is a dioecious species. The plants produced by seeds reach the reproductive stage after approximately 12 to 15 years (Zanette et al., 2011), without having any methods for prior definition of their gender. It is necessary to use the grafting technique for the effective installation of araucaria seed orchards with plants of known quality and early production (Wendling, 2011; Zanette et al., 2011).

It is known that $A$. angustifolia grafting is viable (Wendling, 2011; Zanette et al., 2011), with reports of male plants flowering at four years of age (Wendling, 2011) and female plants at 6.5 years (Wendling, 2015) after grafting by cleft graft (Wendling, 2011). However, the production of $A$. angustifolia grafted plants on a large scale by budding method is still incipient, mainly with the use of flute budding for the purpose of producing multiple shoots, as well as grafting directly in the field.

The grafting performed directly in the field is a promising practice for species. It presents as main advantage in relation to nursery grafting, the formation of a more developed root system, resulting in a rapid and uniform development of shoots and vigorous growth, easily and rapidly forming the aerial part of the plant (Pio et al., 2017). However, according to the same authors, when done in the field, the technique becomes more expensive due to the longer maintenance time of the rootstocks, until it is suitable for grafting, as well as a greater risk of failure to perform it, when incompatible with preexisting anatomical barriers (Melo et al., 2017).

Due to A. angustifolia delay in seeds production, the use of propagation techniques that anticipate the reproductive period may contribute to the formation of clonal orchards, reducing the size of the plants and resulting in greater precocity in the production, since adult propagules have been used as grafts from selected plants in terms of quality and defined gender (Wendling, 2015). However, it is necessary to verify the feasibility and mastery of the grafting technique to be used, which would contribute to the optimization of the time required for multiplication in commercial scale (Kotz et al., 2011b).

Based on the above, the present study aimed at evaluating the feasibility of two grafting methods in A. angustifolia (patch and flute budding) with adult propagules, performed in two seasons of the year and with indoor and outdoor established rootstocks.

\section{MATERIAL AND METHODS}

The experiment was carried out in two seasons of the year: October/2013 (spring) and April/2014 (autumn) in the Laboratory of Forest Species Propagation and in areas close to Embrapa Florestas, located in Colombo, Paraná state, Brazil. Two grafting techniques were studied - patch and flute budding - in two places of establishment of the rootstocks - outdoor (established in the field) and indoor (greenhouse).

The rootstocks used in the experiments were formed from seeds, which were approximately 3 years old in October/2013. The outdoor ones were planted at the field in $3 \mathrm{~m} \times 0.5 \mathrm{~m}$ spacing (between lines $\times$ between plants). The indoor rootstocks were planted in $7 \mathrm{~L}$ plastic 
containers with pine bark commercial substrate, receiving three 15 -min irrigations a day.

The scions used were collected from adult branches with "orthotropic growth tendency", as defined by Wendling (2011), containing from 30 to $45 \mathrm{~cm}$ length, from grafted and already established field trees. These parent trees were grafted with scions from an adult female plant (approximately 30 years old) by cleft grafting, performed in 2007 (Wendling, 2011). At the time of the experiment installation, the branches were collected and packed in a Styrofoam box containing water, in order to avoid dehydration. Their needles were removed only at the time of grafting.

For both techniques, grafting was performed in the subapical region of the rootstock stem. The patch buds were approximately $3 \mathrm{~cm}$ long and $1 \mathrm{~cm}$ wide, with 6 to 8 needles with axillar region (Figure 1A). The flute buds were approximately $2 \mathrm{~cm}$ long and $3 \mathrm{~cm}$ wide, with 10 to 12 needles with axillar region (Figure 1B).

For the patch budding, the grafts were embedded in an open window in the rootstock with identical size (Figure 1C). Two circular and one vertical incision were made for flute budding in order to remove a bark ring to fit the graft (Figure 1D). After the insertion, for both techniques, the buds were fixed with plastic tape, maintaining the aerial part of the rootstock (Figure 1E).

It should be noted that the rootstock diameter was taken into account for the preparation of the patch and flute buddings, and the grafts were performed with size and diameter coincident with the rootstock window. The flute budding was made in a way that completely enveloped the wood of the rootstock, fitting into the window, trying to leave the two vertical ends of the graft as close as possible.

Forty five days after budding (DAB), the plastic tape was removed and the remaining rootstock aerial part was pruned just above the bud. The first evaluation took place at $60 \mathrm{DAB}$, showing the percentage of survival (Figure $1 \mathrm{~F}, \mathrm{G}$ ), vigor of the grafts through average number of shoots with budding (Figure 1H, I) and the number of shoots per graft. The evaluations happened monthly up to $300 \mathrm{DAB}$. During this period, the orthotropic shoots formed in the rootstocks were removed in order to avoid competition with scion shoots.

The experiment was conducted in a randomized block design with factorial treatment arrangement of $2 \times 2 \times 2$ treatments $(2$ seasons $\times 2$ budding techniques $\times 2$ rootstock establishment place) with four replications containing 10 plants per experimental unit for October/2013 and 8 plants per experimental unit for April/2014, totaling 288 grafts. Variances of the treatments were tested for homogeneity by the Bartlett test. Data were submitted to analysis of variance (ANOVA) $(\mathrm{p}<0.05$ and $\mathrm{p}<0.01)$ and the means were compared by Tukey test $(\mathrm{p}<0.05)$.

\section{RESULTS AND DISCUSSION}

Although the evaluations of the experiment occurred up to $300 \mathrm{DAB}$, the presented results refer up to $180 \mathrm{DAB}$ only, as the stabilization of the results occurred from that period on, based on the performed statistical
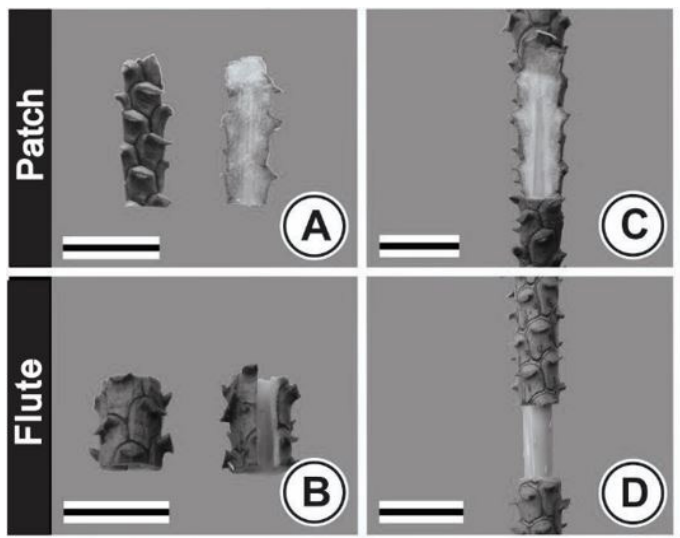
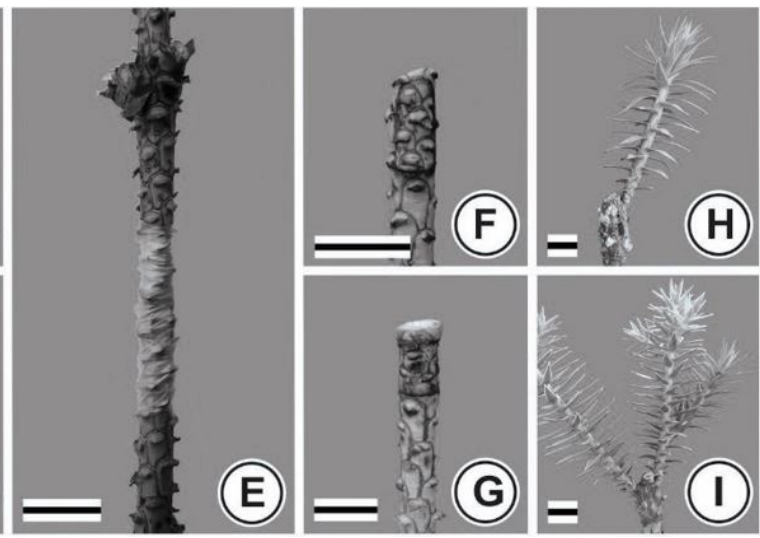

Figure 1. Used budding methods for A. angustifolia. Details of the front and back view of the patch (A) and flute buds (B); graft insertion region in the rootstock in patch (C) and flute (D) budding; plastic tape attachment $(\mathrm{E})$; evaluation of patch $(\mathrm{F})$ and flute $(\mathrm{G})$ survival; graft budding performed by patch $(\mathrm{H})$ and flute (I) budding. Scale $=2 \mathrm{~cm}$. 
analysis. For graft survival, there was a significant interaction $(P<0.01)$ between grafting season and budding techniques from 90 to 180 days. At $60 \mathrm{DAB}$, we observed that the season and budding techniques alone showed a significant influence, contrary to the place of rootstocks establishment.

At $60 \mathrm{DAB}$ it was noted that, for the survival of the grafts, the season and budding techniques are independent, and there was no significant difference for the rootstocks establishment place. When grafting was performed in October, a greater percentage of graft survival was observed (92\%), differing significantly from that made in April (Table 1). This fact may be due to the low metabolic activity of the plants in April (autumn), which may have impaired the cell division for callus formation in the grafting region, causing the lowest survival percentage. Regarding the grafting techniques used, the flute budding had significantly higher indexes (87\%) than those of the patch budding $(74 \%)$ at $60 \mathrm{DAB}$.

From the evaluation of the $90 \mathrm{DAB}$, we observed that the patch budding performed in October showed significantly superior graft survival (averages above $80 \%$ ) compared to April and the flute budding performed in October, as well as in all subsequent evaluations (Table 2).

In relation to the grafting season for flute budding, survival rates were significantly higher for April from the evaluation at $90 \mathrm{DAB}$ to $150 \mathrm{DAB}$, differently from October (Table 2). Due to the larger size of the bud presented in this technique, the mild temperatures of April may have influenced positively, not causing dehydration of the tissues, allowing greater survival of the grafts.

Over the evaluation period, there was apparently a reduction of graft survival in all treatments, with stabilization of the results from $180 \mathrm{DAB}$. This reduction was more drastic for the flute budding in October from the 60 to $90 \mathrm{DAB}$ evaluations (from 50 to $35 \%$ survival), which may indicate the need for a longer time of permanence of the plastic tape, which could also decrease the mortality of patch grafts. These results may be associated with incomplete welding of the graft, leaving it susceptible to oxidation and moisture infiltration (Yin et al., 2012). This survival reduction during a period of evaluation was also observed in other works with patch budding (Kotz et al., 2011a, b; Wendling et al., 2016), assuming that there was poor healing of the bud, leading to death of the scion. However, further studies are needed to clarify these effects.
Similar to the present work, Wendling et al. (2016) reported the reduction of survival in A. angustifolia scions via flute budding technique throughout the evaluations. For the same season of grafting (April/2011), the authors observed survival of approximately $90 \%$ at $30 \mathrm{DAB}$ and approximately $65 \%$ at $120 \mathrm{DAB}$.

Table 1. Survival percentage of $A$. angustifolia grafts as a function of the grafting season (October and April) and of the budding technique used (patch and flute budding) at $60 \mathrm{DAB}$.

\begin{tabular}{cccc} 
Season & \% Survival & Budding & \% Survival \\
\hline October & $92 \mathrm{a}^{*}$ & Patch & $74 \mathrm{~b}^{*}$ \\
April & $68 \mathrm{~b}$ & Flute & $87 \mathrm{a}$ \\
C.V. $(\%)$ & & 21.27 & \\
\hline
\end{tabular}

${ }^{*}$ Means followed by the same lowercase letter vertically do not differ statistically from each other by the Tukey test at the $5 \%$ probability level. $\mathrm{DAB}=$ days after budding; C.V. $(\%)=$ coefficient of variation .

Table 2. Percentage of $A$. angustifolia grafts survival as a function of the grafting season (October and April) and budding technique (patch and flute budding) at 90, 120, 150 and $180 \mathrm{DAB}$.

\begin{tabular}{|c|c|c|}
\hline \multicolumn{3}{|c|}{$90 \mathrm{DAB}$} \\
\hline \multirow{2}{*}{ Season } & \multicolumn{2}{|c|}{ Budding } \\
\hline & Patch & Flute \\
\hline October & $85 \mathrm{aA}^{*}$ & $50 \mathrm{bB}$ \\
\hline April & $52 \mathrm{bB}$ & $69 \mathrm{aA}$ \\
\hline C.V. (\%) & \multicolumn{2}{|c|}{25.27} \\
\hline \multicolumn{3}{|c|}{$120 \mathrm{DAB}$} \\
\hline \multirow{2}{*}{ Season } & \multicolumn{2}{|c|}{ Budding } \\
\hline & Patch & Flute \\
\hline October & $82 \mathrm{aA}$ & $41 \mathrm{bB}$ \\
\hline April & $52 \mathrm{bA}$ & $64 \mathrm{aA}$ \\
\hline C.V. (\%) & \multicolumn{2}{|c|}{29.74} \\
\hline \multicolumn{3}{|c|}{$150 \mathrm{DAB}$} \\
\hline \multirow{2}{*}{ Season } & \multicolumn{2}{|c|}{ Budding } \\
\hline & Patch & Flute \\
\hline October & $82 \mathrm{aA}$ & $36 \mathrm{bB}$ \\
\hline April & $47 \mathrm{bA}$ & $58 \mathrm{aA}$ \\
\hline C.V. (\%) & \multicolumn{2}{|c|}{35.41} \\
\hline \multicolumn{3}{|c|}{$180 \mathrm{DAB}$} \\
\hline \multirow{2}{*}{ Season } & \multicolumn{2}{|c|}{ Budding } \\
\hline & Patch & Flute \\
\hline October & $82 \mathrm{aA}$ & $35 \mathrm{aB}$ \\
\hline April & $41 \mathrm{bA}$ & $52 \mathrm{aA}$ \\
\hline C.V. (\%) & \multicolumn{2}{|c|}{37.29} \\
\hline
\end{tabular}

${ }^{*}$ Means followed by the same lowercase letter lowercase in vertical and upper case in horizontal do not differ statistically from each other by Tukey test at the $5 \%$ probability level. $\mathrm{DAB}=$ days after budding; C.V. $(\%)=$ coefficient of variation. 
Regarding patch grafts with $A$. angustifolia, results report a $65 \%$ survival in the autumn and only $20 \%$ in the spring (Zanette et al., 2011) at 120 DAB with grafting in greenhouse conditions, and 25\% survival when performed in April/2011 (Wendling et al., 2016). The present work had higher survival averages when grafting was performed in the spring (October). There was approximately $82 \%$ of survival from 120 to $180 \mathrm{DAB}$ using patch budding, which is generally the best season to perform grafting in fruit trees (Hartmann et al., 2011). According to the same authors, success at this season is related to mild temperatures. Furthermore, the vascular exchange is in the active form, in full metabolic and mitotic activity, where tissues heal more easily.

A hypothesis for the difference in graft survival results observed in the work of Zanette et al. (2011) compared to the present study can be attributed due to different origins of the used scions. That study used scions from adult trees trunk and shoots, while in the present study, scions from grafted plants were used as source of propagules, characterizing the experiment as a serial grafting.

It is known that the reinvigoration of adult tissues can be induced by grafting, serial grafting and cultural practices (Wendling \& Xavier, 2001; Wendling et al., 2014). Reinvigoration refers only to the return of the plant to a state of high physiological vigor, often confused with rejuvenation (Wendling et al., 2014). Thus, we can assume that branches used as scions for grafting in the present work were more vigorous. Consequently, they have greater potential for survival, compared to the branches used in the study of Zanette et al. (2011), because they were collected from a grafted plant.

The site of establishment of the rootstocks did not interfere in the grafts survival. Thus, there is no need to use a temperature, humidity, and luminosity controlled environment (greenhouse) for the success of the technique. This can be done directly in a field, making the plant's production easier. The importance of the development of the technique in outdoor rootstocks is emphasized. It can avoid or diminish the occurrence of problems as loss of vigor due to the folding of the root system in rootstocks produced indoor (Wendling et al., 2009). Positive results from the use of grafting on outdoor plants were already evidenced by Wendling et al. (2009) and Santin et al. (2015) in Ilex paraguariensis, and by and Reis et al. (2010) in peach trees (Prunus persica L. Batsch).
The percentage of grafts with sprouts showed a significant interaction between grafting seasons and rootstock establishment place at 90 and $120 \mathrm{DAB}$, and between budding techniques and rootstock establishment place at $90 \mathrm{DAB}$. At 150 and $180 \mathrm{DAB}$ there was only significant interaction between the season of grafting and the techniques used.

As distinct from survival, the emission of shoots throughout the assessments showed no clear trend. At $90 \mathrm{DAB}$, there was a higher percentage of grafts with budding when carried out in October in outdoor rootstocks (56\%), differing statistically from the other treatments (Table 3). As for the techniques, in the same evaluation period, there was no significant difference for patch budding in outdoor rootstocks, flute budding in indoor and outdoor rootstocks (Table 3).

Table 3. Percentage of scions with sprouts in A. angustifolia at 90, 120, 150 and 180 DAB.

\begin{tabular}{|c|c|c|}
\hline \multicolumn{3}{|c|}{$90 \mathrm{DAB}$} \\
\hline \multirow{2}{*}{ Season } & \multicolumn{2}{|c|}{ Place } \\
\hline & Indoor & Outdoor \\
\hline October & $29 \mathrm{aB}^{\star}$ & $56 \mathrm{aA}$ \\
\hline April & $6.2 \mathrm{bA}$ & $0 \mathrm{bA}$ \\
\hline \multirow{2}{*}{ Budding } & \multicolumn{2}{|c|}{ Place } \\
\hline & Indoor & Outdoor \\
\hline Patch & $10 \mathrm{bB}$ & $28 \mathrm{aA}$ \\
\hline Flute & $25 \mathrm{aA}$ & $29 \mathrm{aA}$ \\
\hline C.V. (\%) & 35.37 & \\
\hline \multicolumn{3}{|c|}{$120 \mathrm{DAB}$} \\
\hline \multirow{2}{*}{ Season } & \multicolumn{2}{|c|}{ Place } \\
\hline & Indoor & Outdoor \\
\hline October & $38 \mathrm{aB}$ & $58 \mathrm{aA}$ \\
\hline April & $23 \mathrm{aA}$ & $9 \mathrm{bA}$ \\
\hline C.V. (\%) & 51.44 & \\
\hline \multicolumn{3}{|c|}{$150 \mathrm{DAB}$} \\
\hline \multirow{2}{*}{ Season } & \multicolumn{2}{|c|}{ Budding } \\
\hline & Patch & Flute \\
\hline October & $64 \mathrm{aA}$ & $36 \mathrm{bB}$ \\
\hline April & $19 \mathrm{bB}$ & $54 \mathrm{aA}$ \\
\hline C.V. (\%) & 38.83 & \\
\hline \multicolumn{3}{|c|}{$180 \mathrm{DAB}$} \\
\hline \multirow{2}{*}{ Season } & \multicolumn{2}{|c|}{ Budding } \\
\hline & Patch & Flute \\
\hline October & $68 \mathrm{aA}$ & $35 \mathrm{aB}$ \\
\hline April & $20 \mathrm{bB}$ & $48 \mathrm{aA}$ \\
\hline C.V. (\%) & 39.11 & \\
\hline
\end{tabular}

${ }^{*}$ Means followed by the same lowercase letter in vertical and upper case in horizontal do not differ statistically from each other by Tukey test at the $5 \%$ probability level. $\mathrm{DAB}=$ days after budding; C.V. (\%) = coefficient of variation. 
At 120 DAB (Table 3), a larger number of grafts with shoots were observed when grafting was carried out in October in outdoor rootstocks (58\%), differing from other treatments. However, from 150 DAB the season interference on this variable disappeared. At 150 and $180 \mathrm{DAB}$, it is seen that there were significant differences between the budding techniques. For October, the highest percentages were for the patch budding, while for April the flute budding was highlighted.

The issue of shoots started close to $90 \mathrm{DAB}$, with the exception of the grafting performed in April on outdoor rootstocks, which did not present shoots. In the spring season, Zanette et al. (2011) noted that the sprouts of patch budding began only six months after grafting, contrary to the present study. It can be assumed that, for the present study, the needles with axillary region used had high physiological activity, which, after re-establishing their conduction system, quickly began the development of shoots, confirming the success of the grafting.

For the number of shoots per scion, a significant interaction between grafting season and rootstocks establishment site was observed only at 90 and $150 \mathrm{DAB}$ evaluations, highlighting October at $90 \mathrm{DAB}$ at both places (Table 4). There was no significant interaction for the other evaluations, but there were significant differences between treatments within each evaluation. At $150 \mathrm{DAB}$, the grafting made in April in indoor rootstocks was superior to the others, with an average

Table 4. Number of shoots per graft of A. angustifolia regarding season of grafting (October and April) and place of establishment of rootstocks (indoor and outdoor) at 90 and $150 \mathrm{DAB}$.

\begin{tabular}{|ccc|}
\hline & $90 \mathrm{DAB}$ \\
Season & \multicolumn{3}{c}{ Place } \\
\cline { 2 - 3 } & Indoor & Outdoor \\
\hline October & $1.1 \mathrm{aA}^{*}$ & $1.6 \mathrm{aA}$ \\
April & $0.5 \mathrm{bA}$ & $0.0 \mathrm{bA}$ \\
\hline C.V. (\%) & \multicolumn{3}{c}{71.47} \\
\hline \multicolumn{3}{c}{ Place } \\
\hline Season & $\mathbf{1 5 0 \mathrm { DAB }}$ \\
\cline { 2 - 4 } & \multicolumn{3}{c}{ Outdoor } \\
\hline October & $1.4 \mathrm{bA}$ & $1.5 \mathrm{bA}$ \\
\hline April & $3.6 \mathrm{aA}$ & $2.4 \mathrm{aB}$ \\
\hline C.V. $(\%)$ & & 27.95 \\
\hline
\end{tabular}

${ }^{*}$ Means followed by the same lowercase letter in vertical and upper case in horizontal do not differ statistically from each other by Tukey test at the $5 \%$ probability level. $\mathrm{DAB}=$ days after budding; C.V. $(\%)=$ coefficient of variation. of 3.6 shoots per scion (Table 4). The indoor grafting was superior to the outdoor in the evaluation at 120 DAB (Table 5).

In relation to the number of shoots per scion, at 90 $\mathrm{DAB}$ and $150 \mathrm{DAB}$ there was a significant interaction between the site and the grafting season, with emphasis on outdoor in October at 90 DAB (1.6 shoots) and indoor in April at $150 \mathrm{DAB}$ (3.6 shoots) (Table 4). At 120 and $180 \mathrm{DAB}$ (Table 5) it can be observed that the best season for shoot development was October (2.8 at $120 \mathrm{DAB}$ and 3 at $180 \mathrm{DAB}$ ), and the best technique for shoots development was flute budding (2.7 to $120 \mathrm{DAB}$ and 3.5 to $180 \mathrm{DAB}$ ). This greater number of shoots presented by the flute budding is due to the greater amount of axillary buds present in the scion when compared to the patch budding. As for the place, at $120 \mathrm{DAB}$ the plants kept in indoor environment had a better performance ( 2.5 shoots) (Table 5).

The use of patch budding compared to flute budding may be advantageous because of the smaller scion size required for grafting, providing greater

Table 5. Number of shoots per graft of A. angustifolia for grafting season (October and April), budding technique (patch and flute) and place of establishment of rootstocks (indoor and outdoor) at 120 and 180 DAB.

\begin{tabular}{|cc|}
\hline \multicolumn{2}{|c|}{120 DAB } \\
\hline Season & Number of shoots \\
\hline October & $2.8 \mathrm{a}^{*}$ \\
\hline April & $1.3 \mathrm{~b}$ \\
\hline Budding & Number of shoots \\
\hline Patch & $1.4 \mathrm{~b}$ \\
\hline Flute & $2.7 \mathrm{a}$ \\
\hline Place & Number of shoots \\
\hline indoor & $2.6 \mathrm{a}$ \\
\hline outdoor & $1.5 \mathrm{~b}$ \\
\hline C.V. $(\%)$ & 52.57 \\
\hline Season & $\mathbf{1 8 0}$ DAB \\
\hline October & Number of shoots \\
\hline April & $3.0 \mathrm{a}$ \\
\hline Budding & $1.9 \mathrm{~b}$ \\
\hline Patch & Number of shoots \\
\hline Flute & $1.5 \mathrm{~b}$ \\
\hline C.V. $(\%)$ & $3.4 \mathrm{a}$ \\
\hline
\end{tabular}

${ }^{*}$ Means followed by the same lowercase letter in vertical and upper case in horizontal do not differ statistically from each other by Tukey test at the $5 \%$ probability level. $\mathrm{DAB}=$ days after budding; C.V. $(\%)=$ coefficient of variation. 
productivity in plants grafted per branch of propagated material. The execution of the technique is also easier, as well as having a greater chance of compatibility of size (diameter) between the rootstock and the bud, since for flute budding the perfect fit is difficult due to differences in the diameter of the wood, causing difficulty in graft fixation.

The patch budding technique has also shown satisfactory results for the grafting of species such as Araucaria cunninghamii, peach (Prunus persica) and figs (Ficus carica) (Nikles, 1961; Reis et al., 2010; Kotz et al., 2011b). This technique is considered easy to execute and requires less quantity of material to be propagated, producing more grafted plants.

The fact that the flute budding promoted lower survival percentages when compared to the patch budding performed in October may be related to the greater welding area that this type of budding requires, and may not occur completely, making it more sensitive to desiccation. In addition, in the moment of grafting, a deeper cut may have been made into the wood of the rootstock, jeopardizing xylem conduction and impairing the regeneration of vascular tissues. However, the greater number of shoots that the technique presents in relation to the patch budding may be advantageous due to the formation of more branches per graft for the production of seeds. However, studies must be carried out in relation to the production data to confirm this hypothesis.

In the present study, a consistency in the results of the analyzed variables was observed from $180 \mathrm{DAB}$ to $300 \mathrm{DAB}$, without incidence of rejection symptoms. This suggests that, from $180 \mathrm{DAB}$, the use of these types of buddings is not subject to mortality for A. angustifolia. The results presented are promising for the production of selected plants of $A$. angustifolia on a large scale by the grafting method, aiming the production of seeds in a shorter time.

\section{CONCLUSIONS}

The patch budding performed in the spring is the most promising technique for A. angustifolia grafting. It has higher survival and greater sprouting, and is recommended due to the lower demand for propagating material.
A controlled environment is not necessary for the budding techniques used. It is possible to use both rootstocks established in the field and in greenhouses.

After $180 \mathrm{DAB}$ there is a stabilization of the grafts survival percentage, with no losses in the production of grafted plants after this period.

\section{ACKNOWLEDGEMENTS}

Embrapa Forests employees: Décio, Joel, Vero and Nide and to the friends Carlos Stuepp and Rosemeri Fragoso who assisted in the installations of the experiments.

\section{SUBMISSION STATUS}

Received: 25 july, 2017

Accepted: 11 july, 2018

\section{CORRESPONDENCE TO}

\section{Helena Cristina Rickli-Horst}

Universidade Federal do Paraná - UFPR, Rua dos Funcionários, 1540, Juveve, CEP 80035-050, Curitiba, PR, Brasil

e-mail: helenarickli@gmail.com

\section{FINANCIAL SUPPORT}

Conselho Nacional de Desenvolvimento Científico e Tecnológico (476938/2013-9).

\section{REFERENCES}

Anselmini JI, Zanette F. Polinização controlada em Araucaria angustifolia. Cerne 2012; 18(2):247-255. http:// dx.doi.org/10.1590/S0104-77602012000200009.

Carvalho PER. Espécies arbóreas brasileiras. Brasília: Embrapa Informação Tecnológica; 2003.

Danner MA, Zanette F, Ribeiro JZ. O cultivo da araucária para produção de pinhões como ferramenta para a conservação. Pesquisa Florestal Brasileira 2012; 32(72): 441-451. http://dx.doi.org/10.4336/2012.pfb.32.72.441.

Franco G. Tabela de composição química dos alimentos. 9. ed. São Paulo: Atheneu; 2008.

Hartmann HT, Kerster DE, Davies FT Jr, Geneve RL. Plant Propagation: principles and practices. 8th ed. Boston: Prentice Hall; 2011 
International Union for Conservation of Nature - IUCN. IUCN Red List of Threatened Species: version 2013.2 [online]. Gland; 2013 [cited 2017 Feb 24]. Available from: http:// www.iucnredlist.org

Kotz TE, Pio R, Campagnolo MA, Chagas EA, Dalastra IM. Enxertia em figueira 'Roxo de Valinhos' por borbulhia e garfagem. Bragantia 2011a; 70(2): 344-348. http://dx.doi. org/10.1590/S0006-87052011000200013.

Kotz TE, Pio R, Chagas EA, Campagnolo MA, Bettiol JE No, Tadeu MH. Época de coleta das estacas, do uso de fitorregulador de enraizamento e de diferentes tipos de enxertos na produção de mudas de figueira 'Roxo de Valinhos'. Semina: Ciências Agrárias 2011b; 32(1): 31-38. http://dx.doi.org/10.5433/1679-0359.2011v32n1p31.

Melo ETD, Pio R, Balbi RV, Ferreira CA, Mori FA. Anatomic compatibility of pear and quince trees grafted on Pyrus calleryana and Chaenomeles sinensis rootstocks. Pesquisa Agropecuária Brasileira 2017; 52(10): 877-886. http://dx.doi.org/10.1590/s0100-204x2017001000007.

Nikles DG. Araucaria cunninghamii "bark-patch" grafting in the field. Australian Forest Research 1961; 1(1): 45-47.

Pio R, Melo ETD, Bueno JPS, Silva LFDOD, Peche PM, Curi PN. Seminiferous propagation in the selection of chestnut tree rootstocks. Ciência Rural 2017; 47(11): 1-5. http://dx.doi.org/10.1590/0103-8478cr20161010.

Reis JMR, Chalfun NNJ, Reis MA. Métodos de enxertia e ambientes na produção de mudas de pessegueiro $\mathrm{cv}$. 'Diamante'. Pesquisa Agropecuária Tropical 2010; 40(2): 200-205. http://dx.doi.org/10.5216/pat.v40i2.5302.

Santin D, Wendling I, Benedetti EL, Morandi D. Nursery and field serial grafting of Ilex paraguariensis. Pesquisa Florestal Brasileira 2015; 35(84): 409-418. http://dx.doi. org/10.4336/2015.pfb.35.84.903.

Silveira ER, Jamhour J, Ferronato ML, Xavier E, Calgaro EVS. Situação das famílias na extração e comercialização do pinhão em Clevelândia, sudoeste do Paraná. Synergismus Scyentifica 2011; 6(1): 1-6.

Stahl JA, Lobato LP, Bochi VC, Kubota EH, Gutkoski LC, Emanuelli T. Physicochemical properties of Pinhão
(Araucaria angustifolia Bert. O. Ktze) starch phosphates. Food Science and Technology 2007; 40(7): 1206-1214.

Wendling I. Enxertia e florescimento precoce em Araucaria angustifolia [online]. Colombo: Embrapa Florestas; 2011 [cited 2016 June 1]. Available from: http://ainfo.cnptia. embrapa.br/digital/bitstream/item/41903/1/CT272.pdf

Wendling I. Tecnologia de enxertia de Araucaria angustifolia para produção precoce de pinhões [online]. Colombo: Embrapa Florestas; 2015 [cited 2016 June 1]. Available from: http://ainfo.cnptia.embrapa.br/digital/bitstream/ item/125311/1/CT-351-Ivar.pdf

Wendling I, Lavoranti OJ, Resende MDV, Horrmann HA. Seleção de matrizes e tipo de propágulo na enxertia de substituição de copa em Ilex paraguariensis. Revista Árvore 2009; 33(5): 811-819. http://dx.doi.org/10.1590/ S0100-67622009000500004

Wendling I, Stuepp CA, Zuffellato-Ribas KC. Araucaria angustifolia grafting: techniques, environments and origin of propagation material. Bosque 2016; 37(2): 285-293. http://dx.doi.org/10.4067/S0717-92002016000200007.

Wendling I, Trueman SJ, Xavier A. Maturation and related aspects in clonal forestry - part II: reinvigoration, rejuvenation and juvenility maintenance. New Forests 2014; 45(4): 473-486. http://dx.doi.org/10.1007/s11056014-9415-y.

Wendling I, Xavier A. Gradiente de maturação e rejuvenescimento aplicado em espécies florestais. Floresta e Ambiente 2001; 8(1): 187-194.

Yin H, Yan B, Sun J, Jia P, Zhang Z, Yan X et al. Graftunion development: a delicate process that involves cell-cell communication between scion and stock for local auxin accumulation. Journal of Experimental Botany 2012; 63(11): 4219-4232. http://dx.doi.org/10.1093/jxb/ ers109. PMid:22511803.

Zanette F, Oliveira LS, Biasi LA. Grafting of Araucaria angustifolia (Bertol.) Kuntze through the four seasons of the year. Revista Brasileira de Fruticultura 2011; 33(4): 13641370. http://dx.doi.org/10.1590/S0100-29452011000400040. 